\title{
AGE CONSTRAINTS AND DENUDATION RATE OF A MULTISTAGE FAULT LINE SCARP: AN EXAMPLE FROM SOUTHERN ITALY
}

\author{
SALVATORE IVO GIANO and MARCELLO SCHIATTARELLA \\ Dipartimento di Scienze, University of Basilicata, Campus Macchia Romana, Via dell'Ateneo Lucano, 10 - I-85100 Potenza, Italy
}

Received 25 July 2013

Accepted 6 February 2014

\begin{abstract}
The morphological evolution of a carbonate fault line scarp from southern Italy, generated by transpressional faulting and evolved by slope replacement, has been reconstructed. ${ }^{14} \mathrm{C}$ dating of faulted slope deposits (ages included between $18 \mathrm{ka}$ and $\sim 8 \mathrm{ka} \mathrm{BP}$ ) have been performed to constrain the Late Pleistocene - Holocene evolution of that scarp. Long- to short-term denudation rates have been also evaluated for the understanding of the mountain front origin. The slope shows well-defined triangular facets combined with the presence of N-S-striking mountainward-dipping fault planes. The envelope of the slope foot appears slightly curved in a planimetric view and shows an E-W-trending offset in its southern part, making such a feature quite different from the recurrent rectilinear fault scarps, often related to normal faulting. Morphostructural analysis showed that: i) the oldest displacement was generated by a fault with a reverse component of movement; ii) the slope represents an inherited feature, only recently exhumed, and developed starting from a high-angle curved surface; iii) the upper Pleistocene - Holocene extensional faulting has only affected the slope foot and associated waste deposits, causing a series of collateral morphological effects, as fluvial cut of preexisting valleys and the genesis of conspicuous mass movements.
\end{abstract}

Keywords: geomorphology of slopes, ${ }^{14} \mathrm{C}$ dating, denudation rates, southern Apennines, Italy.

\section{INTRODUCTION}

Many papers worldwide have been dedicated to the processes responsible for the development of tectonically-generated slopes and their evolution under different climate conditions and/or deformational regimes, and the original concepts of "fault scarp" and "fault-line scarp" (Johnson, 1939) were continuously modified and enriched (see for example Cotton, 1950; Brunsden [Ed.], 1971; Young, 1972; Wallace, 1977; Burbank and Anderson, 2001; Hartvich and Mentlík, 2010; Hartvich and Valenta, 2013). Further, slope evolution modelling constituted an important issue of some relevant articles since '70s (Kirkby, 1971, 1984) to the last decade (Font et al.,

Corresponding author: S.I. Giano

e-mail: ivo.giano@unibas.it

ISSN 1897-1695 (online), 1733-8387 (print)

C 2013 Silesian University of Technology, Gliwice, Poland.

All rights reserved.
2006), as well as dating of recent fault scarps has traditionally represented a crucial point in morphoneotectonic and seismotectonic investigations (Wallace, 1977; McCalpin and Berry, 1996; Shanov and Dobrev, 1997; Giano et al., 2000; Athanassios et al., 2005; Moro et al., 2007; Ortuño et al., 2008, among others). From this point of view, many of the quoted classical papers pointed out the attention mainly on fault scarps, fault line scarps, or retreated fault slopes generated by block faulting in extensional tectonics. As a matter of fact, few real cases regarding slopes generated under other tectonic conditions and their morphological evolution are more or less consciously reported in the recent literature, although without specific geomorphological descriptions and interpretations. Finally, the Holocene evolution of such mountain fronts, generated under quite different climatic 
and tectonic conditions with regard to the present-day ones, seems to be a promising field of investigation for its potential in detecting the recent morpho-evolutionary trends of a region.

In this paper, we propose an original case-history from southern Italy, where a slope in Mesozoic carbonate rocks generated by transpressional tectonics appears to have all the features of a complex polygenic landform, inherited from Pleistocene times and morphologically reactivated during the Holocene.

The positive carbonate morphostructures of the southern Italian Apennines bound both huge graben-like structures and small endorheic basins scattered along the axial zone of the chain, producing a local relief of hundreds of meters. The ranges of Pollino, Cervati, Alburni, and Maddalena Mts delimitate many of such intermontane basins and are normally featured by roughly rectilinear tectonic mountain fronts, extending for ten or more kilometres. Their basal slope profiles vary from strike to concave. In some cases, when the less recent alluvial floodplains are hung and incised, the basal segments of the adjoining slopes assume a convex profile. The geological setting and the geomorphological characteristics associated to all those slopes may indicate that they have to be interpreted as fault scarps or fault line scarps (Brancaccio et al., 1978, 1979). In other words, slope profiles represent in many cases morphological features useful to define tectonically active fault scarps or fault line scarps (i.e. generated during an older tectonic activity and exhumed by selective erosion, cf. Brancaccio et al., 1986; Ascione and Cinque, 1997).

Many authors (e.g. Ascione and Cinque, 1997), indeed, have suggested that the morphological evidence of fault scarps and fault slopes due to recent or active tectonics are actually rare and, in any case, less frequent than those produced by older deformational stages and successively exhumed. Anyway, it is very difficult to discriminate between the two different modalities because of the well-known convergence phenomena in determining such landforms (Brancaccio et al., 1978). Further, estimates of denudation and/or exhumation rates have been produced in the last decade for the southern Apennines mainly on a regional scale or with regard to fluvial erosion rates, generally by using planation surfaces and other similar landforms, but detailed data about slopes are at recent almost missing. Uplift and erosion rates have been in fact produced and compared by several authors for significant areas of the south-Apennine chain (Amato et al., 2003; Schiattarella et al., 2003, 2006; Martino et al., 2009; Lazzari and Schiattarella, 2010; Gioia et al., 2011), as for examples the entire axial zone of the orogen or the basins of the upper Agri Valley, Melandro Valley, and lower Tanagro Valley, but denudation/recession rates of a single representative slope from those areas have not yet been furnished.

Morphogenetic processes in tectonically active areas produce slope features and associated landforms (as detri- tal talus and alluvial fans) that can help us in recognizing the effects of competition between tectonics and erosion (Ascione and Cinque, 2003). In this paper, we propose a peculiar case-history that has permitted to define a methodological approach and to obtain suitable data on rates of fluvial incision and slope recession based on detailed morphometric measurements and chronological constraints. We analysed a particular retreated slope of tectonic origin, but not generated by normal faulting and located in an area affected by active tectonics (Giano et al., 2000; Moro et al., 2007). This slope, named Coste di Brienza, faces to the Melandro River in its southernmost segment (Pergola Stream), being part of the eastern side of the Maddalena Mts, a $40 \mathrm{~km}$-long NW-SE-trending carbonate ridge, separating different fault-bounded basins of the Campania-Lucania Apennines. The top of the mountain reaches $1445 \mathrm{~m}$ a.s.l. at Tempa delle Rose, whereas remnants of a planation surface are located at about $1300 \mathrm{~m}$ a.s.l. all around the highest point.

\section{REGIONAL AND LOCAL GEOLOGICAL FRAMEWORK}

The Lucanian segment of the southern Apennines (Fig. 1) is made of both deep-sea siliceous-shaly sediments and shallow-water carbonates, mainly Mesozoic in age. The latter group of units constitutes the hanging-wall of a thrust system featuring the axial zone of the chain, whereas the pelagic units represent the footwall of the same regional structure. Both the main tectonic elements are locally covered by Miocene siliciclastic deposits, representing the synorogenic units of the fold-and-thrust system (foredeep deposits). Satellite basins, mainly Late Miocene and Pliocene-Pleistocene in age, are also arranged along the axis of the south-Apennines chain and lay on both the Miocene units and the Mesozoic bedrock. Finally, several sets of Pliocene to Quaternary high-angle faults cut and displaced all the tectonic and stratigraphic units of the Campania-Lucania Apennines (Fig. 2a), and are responsible for the uplift of this sector and the genesis of most of the intermontane basins of the axial zone, included the Pergola-Melandro basin in which the study area is located.

The geology of the studied area fully resembles the regional-scale features above described: the Coste di Brienza slope and the whole mountainous group of Tempa delle Rose are, in fact, made of Triassic dolomite and dolomitic limestone (Fig. 2b) and represent the hangingwall of the regional thrust above mentioned (BrienzaPaterno thrust, after Pescatore et al., 1999). Deep-sea sedimentary successions, known as Lagonegro Units, constitute the footwall of the same thrust. Along the investigated slope, this original low-angle tectonic contact has been cut by a lower Pleistocene N-S-striking upthrust (Fig. 2c).

On a regional scale, Miocene and Pliocene siliciclastic formations from both foredeep and satellite basins 


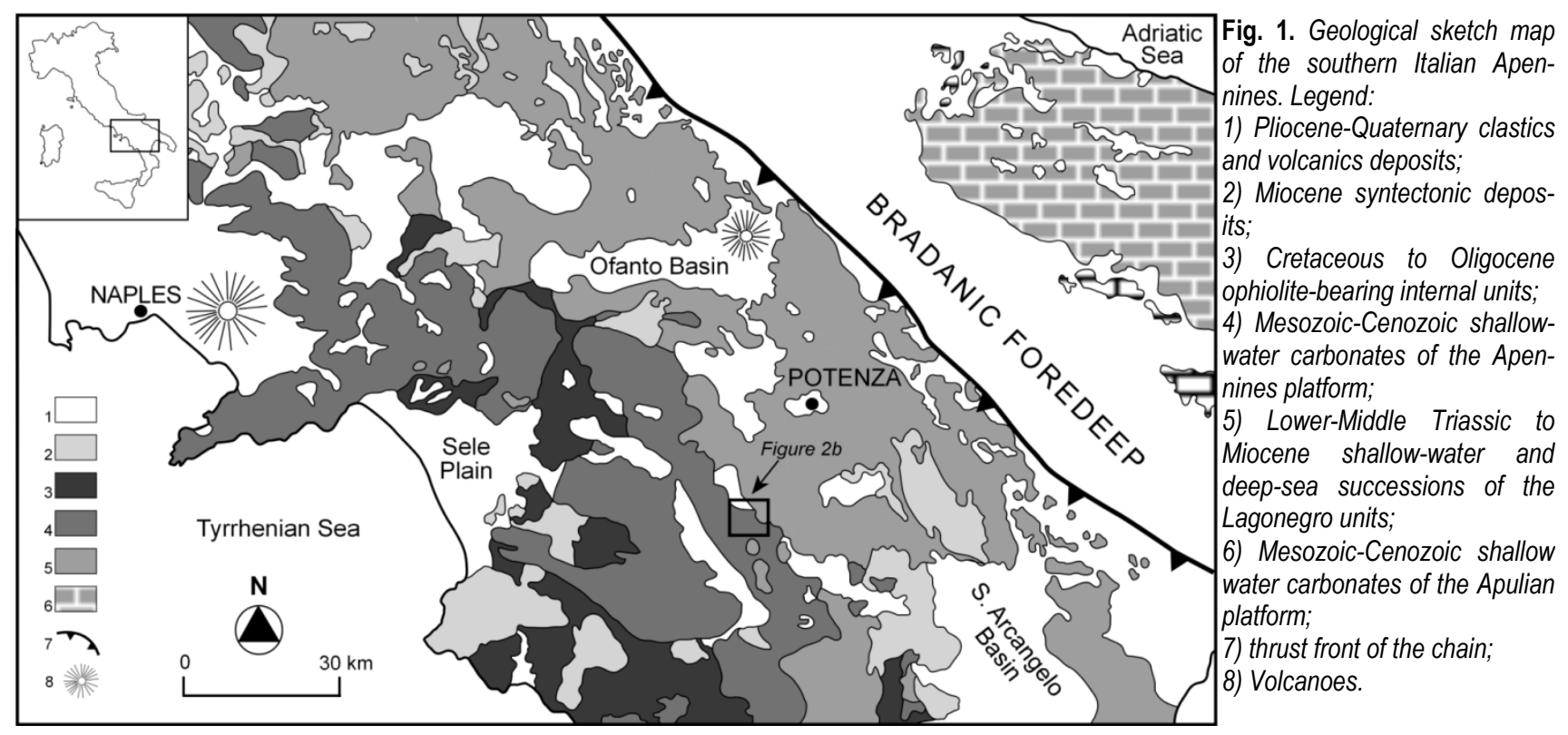

have been also progressively involved in the deformational processes (Pescatore et al., 1999). Thrusting migrated from internal to external domains (i.e. roughly from west to east) during the Miocene, whereas the thrust sequence was of break-back type during Pliocene times, as demonstrated by the ages of the thrust-top basins. In the study area, Pliocene deposits are represented by sand and conglomerate of the "Ciclo di Ariano" succession (Di Nocera et al., 1982), preserved in few outcrops.

Thrust sheets of the axial belt have been severely dismembered by late Pliocene - early Pleistocene $\mathrm{N} 120^{\circ} \pm 10$-striking high angle faults (Russo and Schiattarella, 1992; Cinque et al., 1993), characterised by strike-slip kinematics and associated to N50-60 and N-S sets, then re-activated as extensional faults, starting from mid-Pleistocene times (Schiattarella, 1998).

Geomorphological, stratigraphic, and neotectonic characters of the Pergola-Melandro basin, filled by a thick succession of alluvial sediments, have been investigated by several authors in the last decade (Giano and Martino, 2003; Schiattarella et al., 2003; Martino and Schiattarella, 2006, 2010; Di Leo et al., 2011). A relevant part of these deposits, constituted by a $180 \mathrm{~m}$ thick succession of lower Pleistocene conglomerate and sands, has been exposed by the considerable vertical incision of the fluvial network. On this basis, and using also other morphotectonic markers, uplift rates of about $0.6-0.7 \mathrm{~mm} / \mathrm{a}$ and slip rates on fault planes of $0.3-0.5 \mathrm{~mm} / \mathrm{a}$ and $0.5-$ $0.8 \mathrm{~mm} / \mathrm{a}$, respectively in the $1.8-1.2 \mathrm{Ma}$ and $1.2-0.7 \mathrm{Ma}$ time-spans, have been calculated for the study area and contiguous ranges and basins (Schiattarella et al., 2003, 2006, 2008).

\section{GEOMORPHOLOGICAL AND GEOCHRONO- LOGICAL CONSTRAINTS}

\section{Slope profile analysis}

The eastern slope of Tempa delle Rose Mt. (Coste di Brienza), sited in the left side of the Pergola Stream, which is the main tributary of the Melandro River in its upper valley, is included in a larger positive morphostructure separating the Melandro Valley and the upper Agri Valley (Fig. 2). The geomorphological analysis of the carbonate slope profile (Fig. 3) revealed the existence of two different classes of inclination. The first class developed upward from the footslope, maintaining the same inclination (about $50^{\circ}$ ) over $2 / 3$ of the whole profile. The second (upper) segment shows a constant inclination of $35^{\circ}-40^{\circ}$ up to the top of the slope (Fig. 3). This articulation does not derive from structural or lithological controls, because of the presence of limestone and dolostone layers with constant thickness and the same attitude forming the entire Coste di Brienza slope, but is clearly originated by a mechanism of slope replacement (or cliff recession, after Young, 1972), showing the typical association of landforms of polyphased retreated slopes, as already widely recognized in the southern Apennines carbonate massifs (Brancaccio et al., 1979). It has been in fact postulated that such slopes represent the product of alternate climate conditions switching from periglacial conditions, responsible for the retreat of the slopes and eventual formation of free faces, to warm-humid conditions, producing the transversal dissection by streams and the consequent genesis of triangular or trapezoidal facets (Fig. 4). 


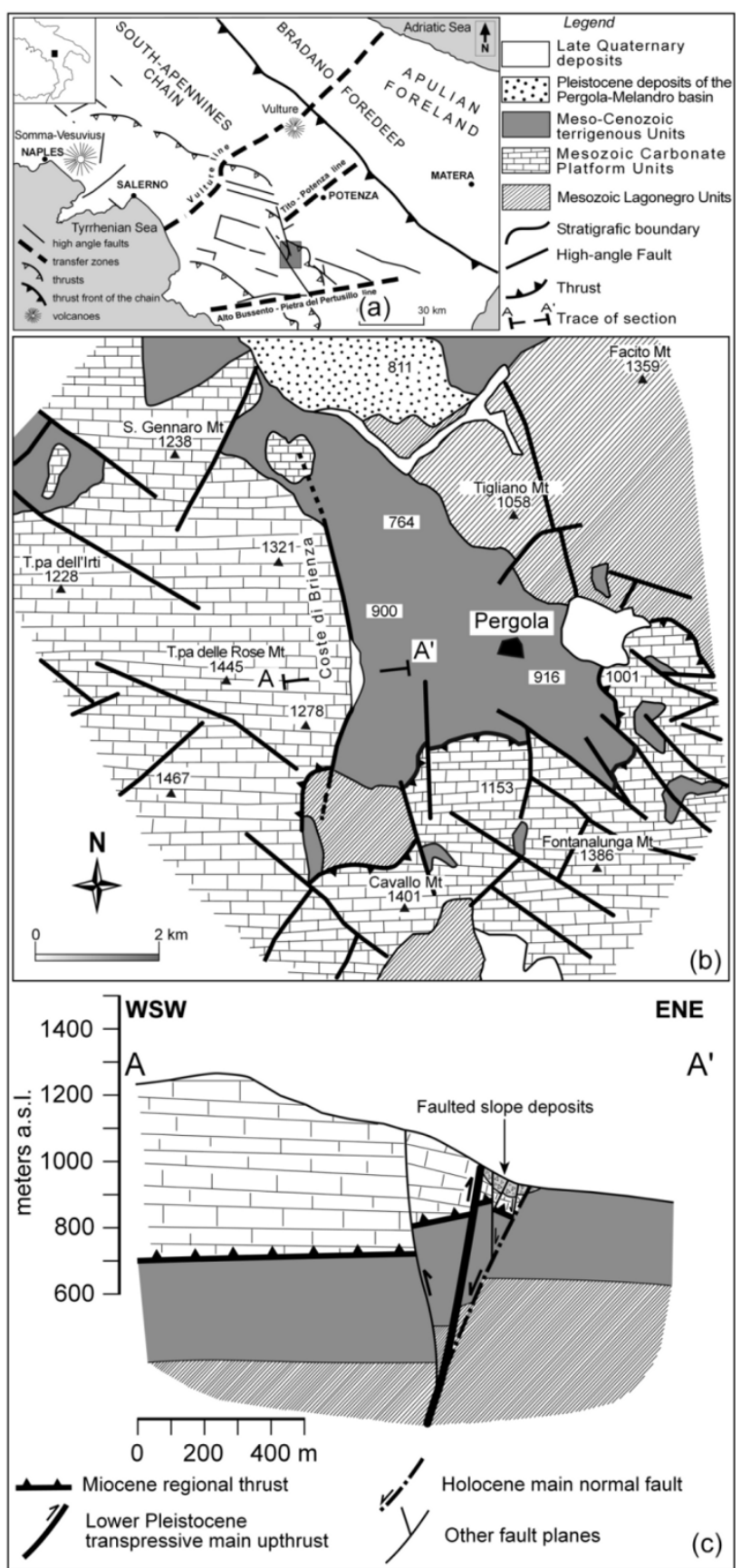

Fig. 2. Location of the study area in the tectonic scheme of the southern Apennines (a), geological sketch map of the Tempa delle Rose Monte Facito mountainous group (b), and geological cross section showing the structural characteristics of the tectonic contact between Mesozoic carbonates and deep-sea (i.e. Lagonegro) units, displaced by high-angle faults and buried by faulted Quaternary sediments (c); both the lower Pleistocene transpressional and Holocene extensional main faults have been drawn with ticker strokes.
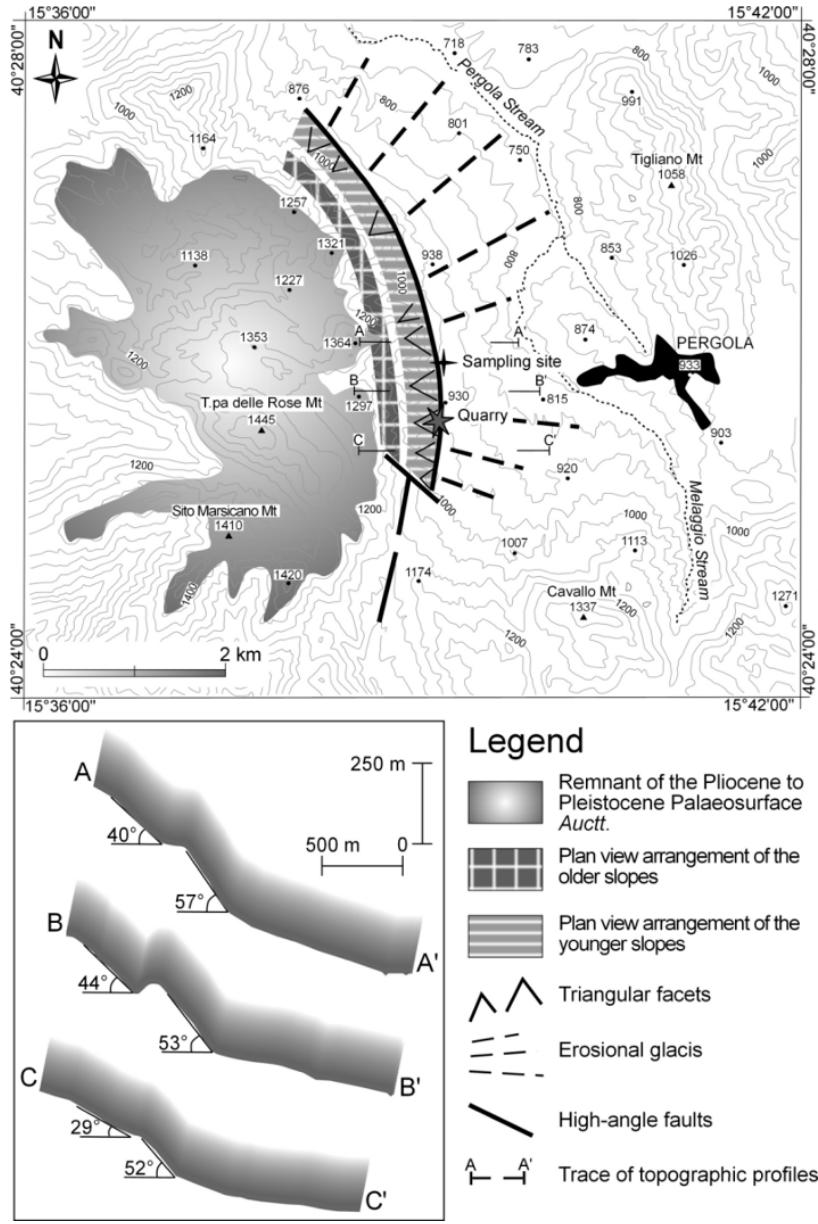

Fig. 3. Morphostructural setting of the study area. Curvilinear envelope of the foot of the slope and layout of the multistage slope are pointed out. First and second generation slope angles are reported in the lower frame.

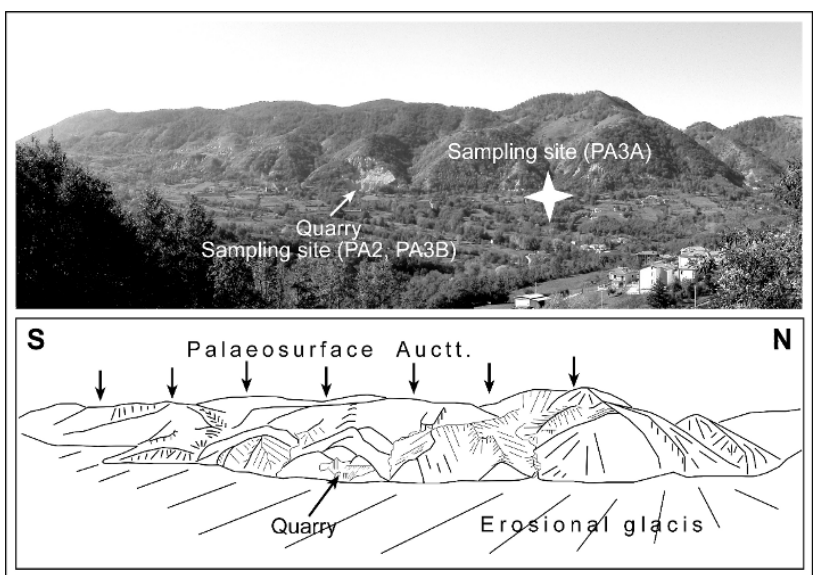

Fig. 4. General view of the Coste di Brienza mountain front. PliocenePleistocene land surface at the top and erosional glacis at the base of the slope are recognizable. In the line-drawing, triangular facets and curvilinear trend of the mountain front are pointed out. 
The studied slope shows a sharp change in acclivity, featuring a rocky concave-rectilinear segment and a concave-upward detrital talus at its base. At the foot of the slope, a $2 \mathrm{~km}$-large and a $7^{\circ}$ to $19^{\circ}$-inclined erosional glacis is present (Figs. 3 and 4). It is sculptured in claydominated Lagonegro units and Miocene terrigenous successions, both affected by diffuse mass movements which reach the present-day thalweg of the Pergola Stream.

At the top, the carbonate slope passes to a subhorizontal surface (Fig. 4), representing a remnant of a regional planation surface, late Pliocene - early Pleistocene in age (Schiattarella et al., 2003, 2006; Boenzi et al., 2004; Gioia et al., 2011).

In a plan view, the $7 \mathrm{~km}$-long mountain front is characterized by an N-S-trending slightly curved basal envelope. Its southern tract is displaced by a $200 \mathrm{~m}$-long planimetric offset due to an E-W-striking transfer fault (Fig. 3).

All these morphological characteristics make this slope different from the recurrent fault scarps with a straight fault trace at the base of the slope, often related to normal faulting, as largely observed in the adjacent areas. The absence of both lateral continuity and rectilinear basal envelope, typically featuring the retreated fault slope generated by normal faulting in the calcareous Apennines (Brancaccio et al., 1979), and the presence of landforms of different genesis and age allowed us to interpret it as a peculiar type of fault line scarp.

Mesoscopic analysis of faults and associate brittle structures (Fig. 5), carried out in well-exposed outcrops (quarry in Figs. 2 and 4), revealed that the tectonic contact between Mesozoic shallow-water carbonates and pelagic shale ("Flysch Rosso" Auctt.), originally due to a regional thrust (Pescatore et al., 1999), then re-activated as a low-angle extensional fault (Schiattarella et al., 2006), is cut by a transpressional high-angle fault (Giano et al., 2000). This surface strikes about N-S and dips mountainward. It did not retain any morphological step, being erased by the slope retreating process, and is locally sutured by detrital and/or colluvial deposits. The highangle fault set cutting the Mesozoic carbonate bedrock (Fig. 5a) have been produced within a stress field compatible with that of the contractional and/or transpressional tectonics of the southern Apennines (Miocene to early Pleistocene in age in the axial zone of the orogen), as demonstrated by the analysis of the $\mathrm{P}$ and $\mathrm{T}$ axes calculated for the same fault population (Fig. 5b).

Fault generation and the evolution of a consequent curviplanar slope, showing a morphological vertical offset of about $300 \mathrm{~m}$, are caused by the activity of a major $\mathrm{N} 120^{\circ}$-trending left-lateral strike-slip brittle shear zone, crossing the morphological boundary between the southern sector of the Melandro Valley and the northern apex of the Agri Valley, acting at least since the early Pleistocene (Schiattarella, 1998).

\section{Slope deposits}

At the foot of the carbonate slope, a N-S-striking normal fault and related synthetic and antithetic minor structures displaced a waste deposits with carbonate clasts and interbedded red-brownish palaeosols, producing a pluri-metric offset (Fig. 6). The faults displacing the detrital talus and associated palaeosols, collected in the quarry area and north of this site, have been clearly generated by an extensional, younger episode of brittle deformation (Fig. 5c).

Dating based on the presence of organic matter, performed by means of both conventional ${ }^{14} \mathrm{C}$ and $\mathrm{AMS}{ }^{14} \mathrm{C}$ methods (Table 1) on one of the interbedded palaeosols (Fig. 6a, b), has been carried out.

The PA3A sample site crops out at about $700-800 \mathrm{~m}$ to the north of the quarry area and at the base of the carbonate slope (see Figs. 3 and 4 for location). Here, a trench for building foundation shows a wall of $5 \mathrm{~m}$ thick formed by the Triassic carbonate unit overlapped by the Pleistocene slope breccia and palaeosols (Fig. 6a). This deposits is constituted of four different stratigraphic horizons, as follows (from the bottom to the top): 1) a lower palaeosol of 10-15 cm in thickness, composed of brown silt; 2) a crudely stratified breccia formed by limestone clasts and clayey silt matrix; 3) an upper palaeosol of

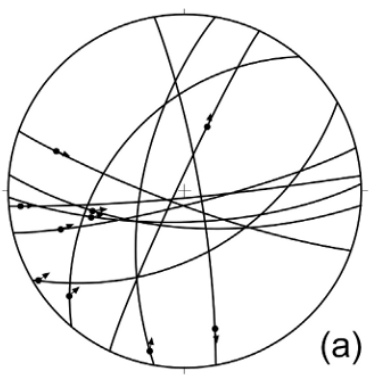

(a)
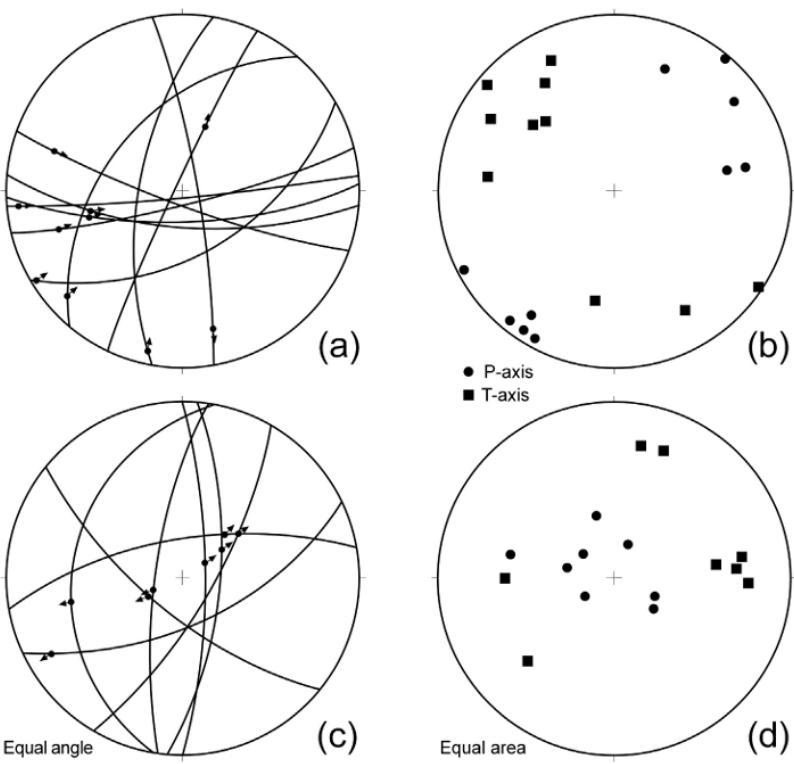

Fig. 5. a) Stereoplot of the fault set cutting the Mesozoic carbonate bedrock of the Coste di Brienza slope (Wulff Net, lower hemisphere), b) $P$ and $T$ axes calculated for the same fault population (Schmidt Net, lower hemisphere), c) stereoplot of the fault set displacing the talus deposits at the base of the slope (Wulff Net, lower hemisphere), and d) $P$ and $T$ axes calculated for the same fault population (Schmidt Net, lower hemisphere). It is remarkable that the fault planes of the stereogram a) have been produced within a stress field compatible with that of the contractional and/or transpressional tectonics of the southern Apennines, whereas the faults reported in the stereoplot c) have to be generated by an extensional strain with a counter-Apennines axis. 
$15-20 \mathrm{~cm}$ in thickness, constituted by red-brown silty clay; 4) a brown clay layer of $10-15 \mathrm{~cm}$ in thickness, including small-size limestone clasts (Fig. 6a, b). The sample PA3A comes from the lower palaeosol faulted and tilted mountainward. According to Giano et al. (2000), the PA3A sample furnished a ${ }^{14} \mathrm{C}$ conventional age of $18,037 \pm 261 \mathrm{BP}(21,818-21,152 \mathrm{cal} \mathrm{BP}$; adopting new calibration curve IntCal13 (Reimer et al., 2013) and OxCal programme by Bronk Ramsey (Bronk Ramsey and Lee, 2013) this age interval is $22,220-21,540$ cal BP); in this work, the same sample has been re-dated with the ${ }^{14} \mathrm{C}$ AMS method showing an age of 17,380 \pm 100 BP (cf. Table 1).

Both the PA2 and PA3B samples (cf. Table 1), outcropping in the quarry site (see Figs. 3 and 4 for location), are in the footwall of the Pergola fault (Fig. 7). They belong to a $10-15 \mathrm{~cm}$ thick palaeosol layer formed by brown silt and clay. The ${ }^{14} \mathrm{C}$ AMS age of the PA2 and PA3B samples are 14,330 $\pm 90-15,040 \pm 80$ BP (Table 1), respectively. The morphological and stratigraphic correlation of the slope deposits has permitted us to assign the PA3A, PA2, and PA3B to the same palaeosol. The ${ }^{14} \mathrm{C}$ AMS technique applied at the R.J. Van de Graaff Laboratory of the Utrecht University, basically confirms the age of about $17 \mathrm{ka}$ of the PA3A sample, already attributed to $18 \mathrm{ka}$ by Giano et al. (2000). Such ages (Table 1) suggest to possibly include the fault episode in the temporal range of the active tectonics (sensu Machette, 2000). The same conclusions were reached by Moro et al. (2007), which dated three different horizons within the sedimentary body cropping out at the foot of the slope in the quarry area (Fig. 7). In particular, ${ }^{14} \mathrm{C}$ ages have been attributed to the three levels interbedded in the slope deposits as follows (from the bottom to the top): i) $11,510 \pm 60 \mathrm{BP}(13420-13290 \mathrm{cal} \mathrm{BP}$, lower dark palaeosol); ii) $9,130 \pm 40$ BP $(10340-10220$ cal BP, pedogenic colluvium); $6,640 \pm 70$ BP $(7580-7470 \mathrm{cal}$ $\mathrm{BP}$, sandy-silty colluvium). These ages are in good agreement with the chronological data presented in this paper, being the red-brownish palaeosol which gave an AMS ${ }^{14} \mathrm{C}$ age of $\sim 14-15 \mathrm{ka} \mathrm{BP}$ (PA2 and PA3B samples in Table 1) a correlative of a similar level positioned beneath the dark palaeosol ( $11 \mathrm{ka} \mathrm{BP}$, after Moro et al., 2007). On the other hand, the physical characters of these two palaeosols are quite different, suggesting that the oldest probably developed under more arid climate conditions.

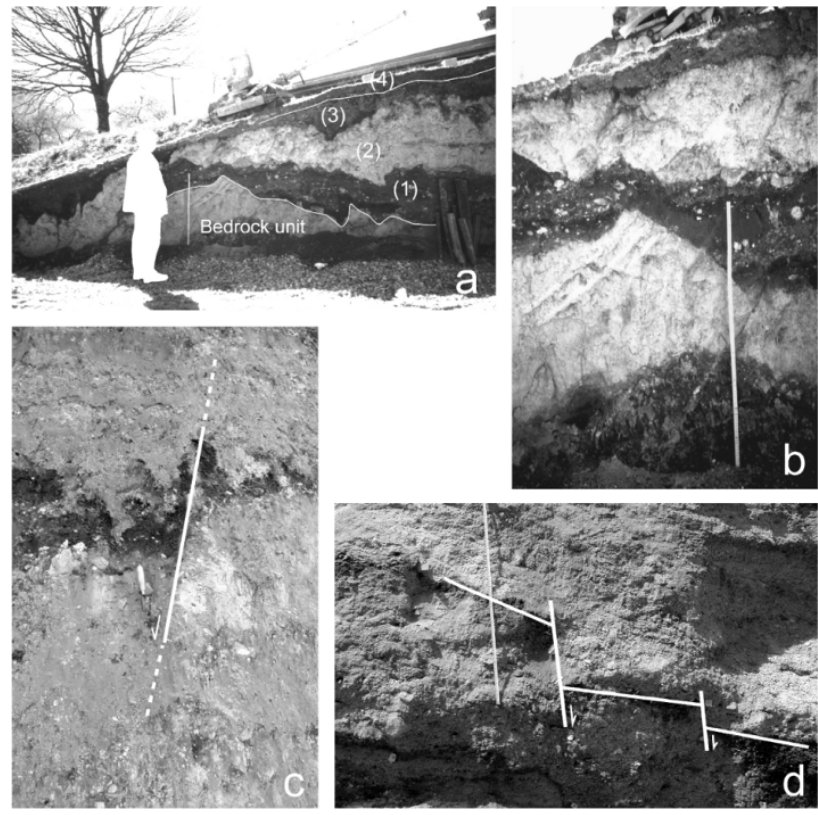

Fig. 6. Slope deposits and interbedded palaeosols: a) sampling site of the PA3A faulted palaeosols $\left({ }^{14} \mathrm{C}\right.$ age of about $\left.14 \mathrm{ka}\right)$ outcropping in the central sector of the mountain front (see text for the meaning of the numbers); b) detail of the sampled palaeosol; c) faulted palaeosol interbedded in the Santa Domenica breccia (Giano and Martino, 2003), in the northern sector of the mountain front; d) synsedimentary antithetic faults deforming a thin palaeosol outcropping in the quarry area of the southern part of the slope (cf. Fig. 3).

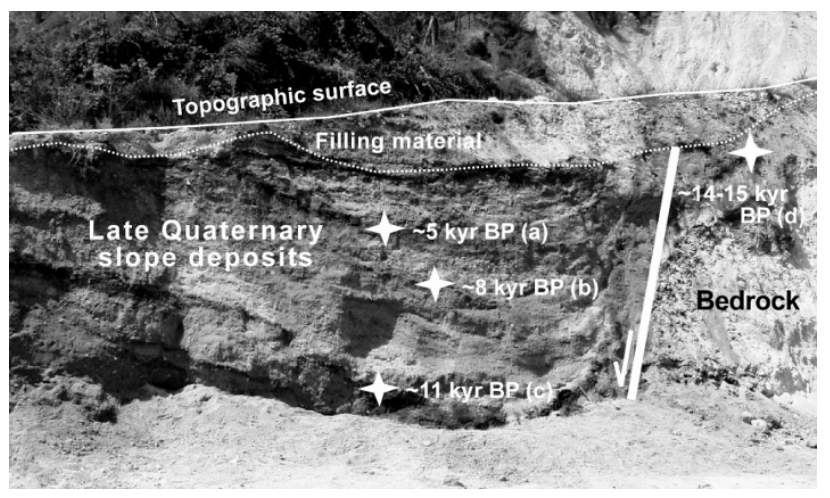

Fig. 7. Outcrop of the faulted slope deposits (talus breccia and interbedded palaeosols) in the quarry area (see Fig. 3 for its location and text for further explanation). The samples labelled with letters $(a, b, c)$ have been dated by Moro et al. (2007), whereas the d-labelled sample has to be referred to the present work.

Table $1 .{ }^{14} \mathrm{C}$ AMS ages of the faulted palaeosol outcropping near the Pergola village. Calibration of ${ }^{14} \mathrm{C}$ dates was made using OxCal programme (Bronk Ramsey and Lee, 2013) and calibration curve IntCal13 (Reimer et al., 2013).

\begin{tabular}{clccccc}
\hline Sample & Fraction analysed & $\begin{array}{c}\text { Mass } \\
(\mathbf{m g})\end{array}$ & Lab. code & $\begin{array}{c}\delta^{13} \mathbf{C} \\
(\%)\end{array}$ & $\begin{array}{c}\text { Age }{ }^{14} \mathbf{C} \\
(\mathrm{BP})\end{array}$ & $\begin{array}{c}\text { Calendar Age } \\
\text { (cal BP) }\end{array}$ \\
\hline PA2 & Res organic matter & 1.790 & UtC-9552 & -25.8 & $14330 \pm 90$ & $17,610-17,320$ \\
PA3A & Res organic matter & 1.820 & UtC-9553 & -25.7 & $17380 \pm 100$ & $21,140-20,800$ \\
PA3B & Res organic matter & 2.230 & UtC-9554 & -25.2 & $15040 \pm 80$ & $18,400-18,150$ \\
\hline
\end{tabular}




\section{DISCUSSION OF RESULTS}

\section{Morpho-evolutionary sequence}

The Coste di Brienza slope and the whole mountainous group of Tempa delle Rose, made of Triassic dolomite and dolomitic limestone (Fig. 2b), represent the hanging-wall of the Brienza-Paterno regional thrust (Pescatore et al., 1999), whereas deep-sea sedimentary rocks constitute its footwall. This low-angle tectonic contact has been cut by a N-S-striking upthrust (Fig. 2c), lower Pleistocene in age, responsible for the creation of the embryonic relief.

Morphological and structural analyses have enlightened the existence of two distinct deformational stage in the evolutionary history of the Coste di Brienza slope: the first is expressed by transpressional faults acting since the beginnings of the early Pleistocene, responsible for the genesis of an obsequent fault line scarp; the second stage should be assigned to the late Pleistocene - Holocene passage and is represented by a surface faulting which did not produce a significant morphological offset.

Denudation processes led to the exhumation and shaping of the slope during a lower Pleistocene long-lasting stage. Internal (i.e. ocean-derived) units, tectonically lying on the Mesozoic carbonates, and the flysch units covering the same calcareous and dolomitic successions was dismantled in $\mathrm{n} \times 10^{5} \mathrm{yr}$-long time-span, and the carbonate rocky slope underwent a polyphased morphoevolution by slope replacement mechanisms and transversal fluvial dissection. Due to such a morphoevolutionary sequence (Fig. 8), including the two-step faulting, the studied slope testifies a process more complex than the simple retreat of a scarp generated by normal faulting. The multistage sequence is articulated as follows:

- first stage: a flexure deforming the terrigenous units at the top of the stack, generated by a transpressional blind upthrust propagating through the underlying carbonate rocks, produced an offset of several hundreds of meters (Fig. 8a). As a consequence of the flexure-induced change of the erosion base level, the dismantling of the terrigenous units by selective erosion and the related exhumation of the Mesozoic limestone were favoured, first in the hanging-wall (higher relief) and then in the footwall of the upthrust; - second stage: an embryonic landscape planation process provoked the rapid retreat of the first generation obsequent fault scarp (Fig. 8b) and the reworking of the pre-existing upper Pliocene - lower Pleistocene summit land surface (palaeosurface or "Paleosuperficie" Auctt., S1 after Schiattarella et al., 2003, cf. age constrain in Gioia et al., 2011);

- third stage: both the regional uplift at about $1.2 \mathrm{Ma}$ ("Emilian" tectonic stage, cf. Ruggieri et al., 1984), responsible for the displacement of the palaeosurface, and the instauration of a humid climate regime, favouring the fluvial erosion, promoted the vertical in- cision by streams of the morpho-structural low previously created; successively, the lateral planation of the valley in a steady-state fluvial condition, produced an erosional glacis in the shaly Lagonegro-type units of the downthrown block (Fig. 8c);

- fourth stage: the whole amount of the ancient waste deposits was evacuated by streams; the detrital talus at the foot of the carbonate slope has to be referred to recent times, for it contains the palaeosols (dated at 14-17 ka $\mathrm{BP}=17.3-21.1 \mathrm{ka}$ cal $\mathrm{BP}$ ) suturing the transpressional fault (Fig. 8d);
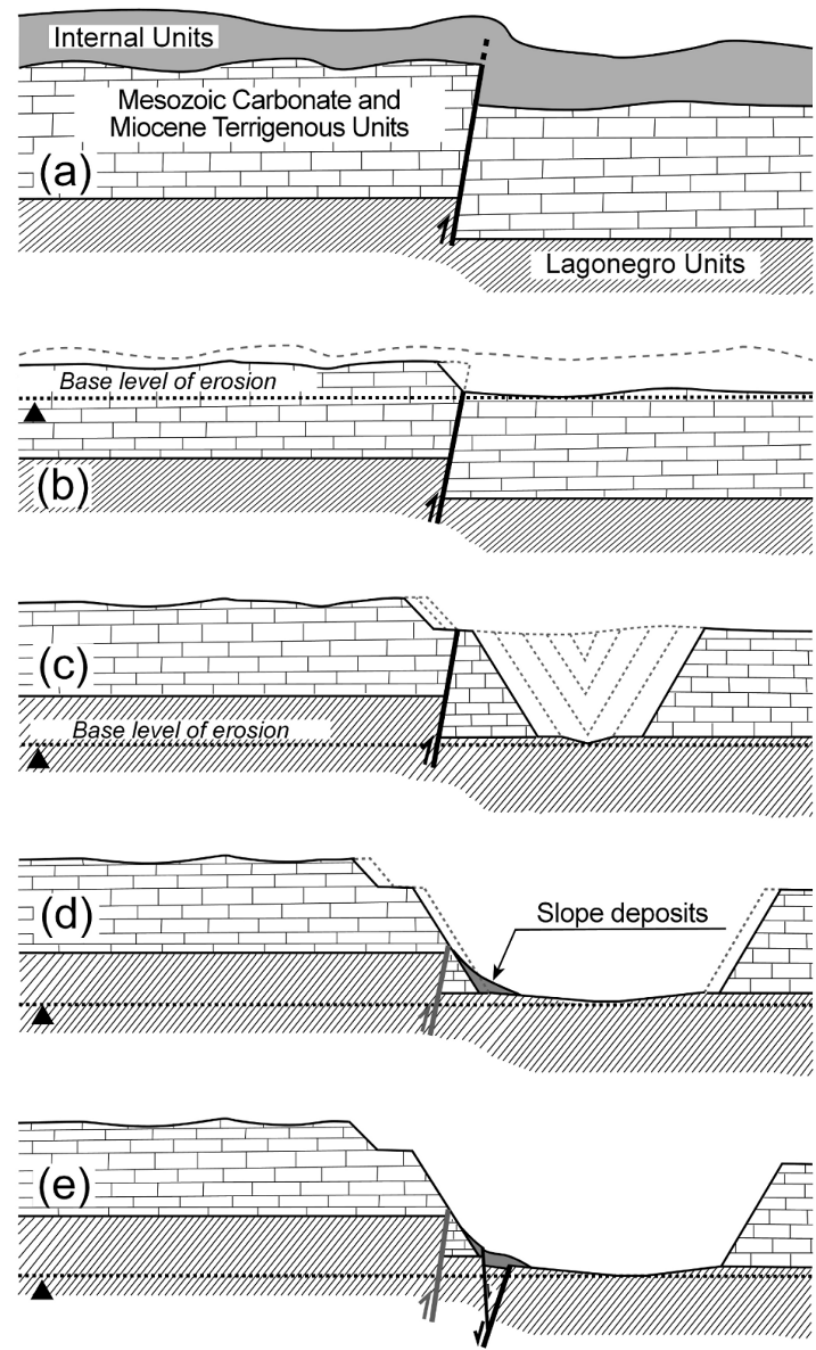

Fig. 8. Morpho-evolutionary model of the study area. Steps: a) starting conditions: tectonic stack formed by internal and external units, affected by lower Pleistocene transpressional faulting; b) regional tectonic uplift and consequent lowering of the base level, causing exhumation of the Mesozoic carbonate, first in the hanging-wall block and then in the footwall of the transpressional upthrust, with consequent exposition of the original retreating obsequent scarp (dashed line); c) valley incision and widening as a consequence of a new change of the base level of the erosion, due to tectonic uplift; d) lateral planation of the valley and creation of an erosional glacis; e) normal faulting at the foot slope, displacing recent waste deposits. 
- fifth stage: the final step (Fig. 8e) is related to the normal faulting at the base of the carbonate slope during the late Pleistocene and the Holocene, causing the pluri-metric displacement of the recent detritalcolluvial deposits and associated palaeosols, at present without any morphological expression in the slope profile. This stage cannot be viewed as a gravitational response of the steep slope because the fluvial incision occurs far away from the mountain front of some kilometres, as evidenced by the existence of a large erosional glacis, and also because such an extensional stage is recognizable along the entire slope.

This sequence of multistage scarp development represents a speculative model of evolution of a mountain front, based on regional and local assumptions, strictly deriving from observations about geomorphological processes and associated landforms. The vertical incision of the major palaeoriver started in correspondence of a morphological low (i.e. the right block in Fig. 8b). Although its original position remains undetermined, this uncertainty is not relevant in the evolutionary model here proposed. The absence of significant amount of slope deposits produced by lateral planation (cf. third stage in Fig. 8) could be explained by the fluvial discharge that has transported downstream such deposits.

The existence of both the first and second stages (formation of the original buried scarp and dismantling of the terrigenous covers) has been deduced by studies on the regional exhumation processes (see for example Aldega et al., 2005; Schiattarella et al., 2006; Mazzoli et al., 2008), also affecting the Coste di Brienza site. The attribution of the starting of fluvial incision (third stage in Fig. 8) to the Emilian marine stage is instead based on the fact that a significant climate change (from a cold period in the Calabrian marine stage to a warmer period in the Emilian stage, cf. Ruggieri et al., 1984, and more recently, Ciaranfi et al., 2010) occurred during the early Pleistocene in the Mediterranean area.

The chronological constrains based on the ${ }^{14} \mathrm{C}$ radiometric dating helped us in demonstrating that the recent (or active) faulting cannot be accounted for the genesis and evolution of the Coste di Brienza slope, and that the brittle deformation occurred along a mountainous front already morphologically evoluted. In other words, the area was involved in active faulting that produced small displacements at the base of the slope of a previously shaped mountainside. It is well-known that the characterization of a mountain front affected by active tectonics requires the recognition of structural and geomorphic features (Athanassios et al., 2005; Ortuño et al., 2008, among others). On this basis, the fault plane analysis and the arrangement of the geomorphic markers (planation surfaces, triangular facets, incised valleys, etc.) of the Coste di Brienza mountain front allowed us to recognize a polyphased fault line scarp generated under a transpressional tectonic regime and successively affected by normal faulting at its foot in very recent times. The Holocene main fault is expressed by a mountainward-dipping plane, associated to a set of minor antithetic faults, which basically represents the re-activation by inversion of the preexisting transpressive upthrust. This caused an episode of footwall uplift (i.e. the glacis between the carbonate slope and the present-day talweg was uplifted with regard to the adjacent mountain ridge) and the fluvial network running on the terrigenous formations deepened their riverbeds. Such a morphological effect may be schematically represented by the block diagram d) of Fig. 9, where different given conditions have been compared. Similar settings have been illustrated by Krzyszkowski and Stachura (1998) for the Middle Sudeten Mts in south-western Poland, where the development of postglacial valleys was controlled by differential uplift and/or fault activity. Widespread landslides in the clay-dominated units outcropping in front of the carbonate slope may represent a further collateral effect of the Holocene tectonic activity.

\section{Pleistocene vs. Holocene denudation rates}

The comparison of denudation and/or exhumation rates with the tectonic uplift rates may furnish a powerful key to detect the dynamic state of the orogenic chains. Such data have been produced worldwide mainly on a regional or sub-regional scale by using planation surfaces and other morphological markers.

In this study, we provide estimates based on observations about a single mountain front, reinforced by a detailed description of the site and well-constrained field and chronological data. Further, we try to discriminate the Holocene denudation rate from those relative to the whole history of the slope-to-glacis area.

Pleistocene erosional processes in the area close to the Pergola village in the Melandro Valley lead to the exhumation of the carbonate morphostructure of Mt. Tempa delle Rose. Its eastern slope (Coste di Brienza) resulted from the multistage evolution of an obsequent reverse fault scarp, developing for about $150 \mathrm{~m}$ in height $(\Delta \mathrm{h}$ in Fig. 10). The time interval extending from the creation of the original scarp to the complete dismantling of the terrigenous covers ( $a$ to $b$ stages in Fig. 8), up to the triggering of fluvial incision by the Emilian tectonic stage (start of c stage in Fig. 8), is included between the end of the Gelasian (about 1.8 Ma) and the Emilian-Sicilian marine stages boundary (about 1.2 Ma). On this basis, we calculate a conservative estimate of the exhumation rate in the time-span included between 1.8 and $1.2 \mathrm{Ma}$, which is equal to $0.25 \mathrm{~mm} / \mathrm{a}$. The successive local relief growth produced by the vertical incision of the drainage network from the early Pleistocene until now (c to e stages in Fig. 8) determined an average morphological offset of $350 \mathrm{~m}$ ( $\Delta \mathrm{H}$ in Fig. 10), and a total difference in height of about $650 \mathrm{~m}$ starting from the top of Mt. Tempa delle Rose (Fig. 3). Assuming $\Delta \mathrm{H}$ as the maximum difference in height for the calculation of the bedrock incision rate (sensu Burbank and Anderson, 2001) in the time-span included between 1.2 Ma and the Present, a value of 


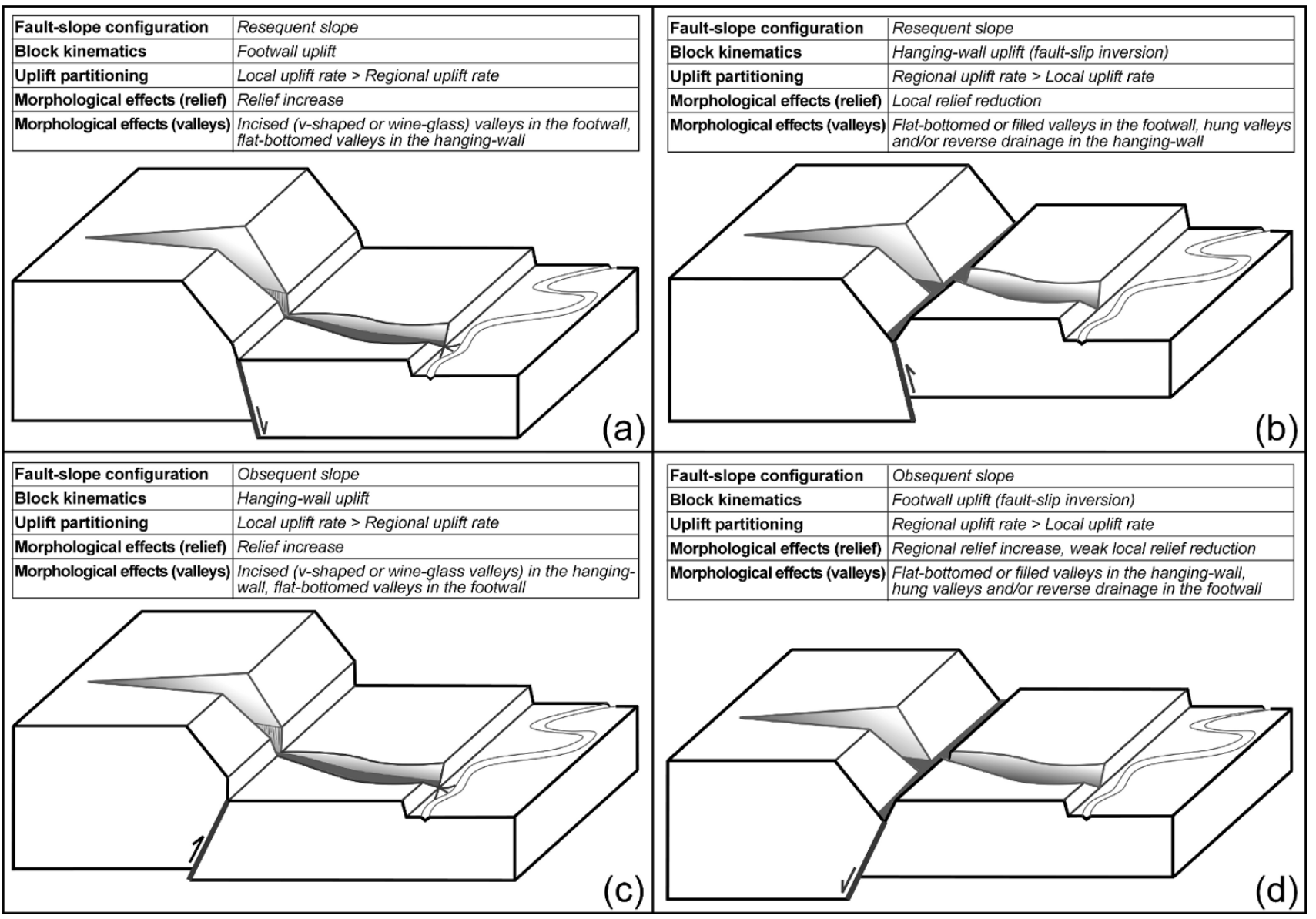

Fig. 9. Block-diagrams showing four hypothetic morpho-structural settings of the slope-glacis couple resulting from different tectonic conditions (see charts for every single case). The mountain front of Coste di Brienza resembles the case c) for its Pleistocene history and the case d) for its Holocene evolution.

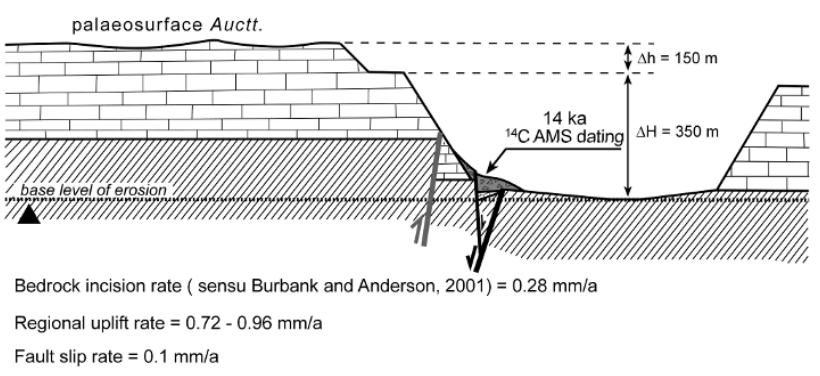

Fig. 10. Schematic slope profile and other elements for the calculation of uplift and erosion rates.

$0.29 \mathrm{~mm} / \mathrm{a}$ can be obtained. The rate of the total vertical incision starting from the "Calabrian" tectonic stage (about 1.8 Ma, i.e. the previous Pliocene-Quaternary Boundary; see also Table 1 in Schiattarella et al., 2003) to the Present, obtained by summing the two distinct offsets $(\Delta \mathrm{H}+\Delta \mathrm{h})$, is equal to $0.28 \mathrm{~mm} / \mathrm{a}$ (Fig. 10). This value appears to be constant during most part of the mor- pho-evolution of the studied area, as suggested by the comparison with the erosion rate estimated for the shorter time interval. Further, both values are in good agreement with those $(0.2-0.3 \mathrm{~mm} / \mathrm{a})$ calculated by several authors for different sectors of the southern Apennines and similar temporal ranges (Amato et al., 2003; Martino and Schiattarella, 2006, 2010; Schiattarella et al., 2006, 2008). Yet, if we calculate the vertical incision rate for the last 8-9 ka (i.e. after the last faulting episode of palaeosols and colluvium), based on the amount of recent fluvial cut of the rocks in the footwall of the main fault of Mt. Tempa delle Rose (i.e. based on the measurement of the lower part of the transversal profiles of wine-glass valleys, showing river carvings of about 5-6 meters at least), we obtain a value of about $0.6 \mathrm{~mm} / \mathrm{a}$. Such an high value could be due to the cumulate effects of the average behaviour of the streams, triggered by the regional uplift, and the local episode of footwall uplift (Fig. 9d). It is worth noting that that maximum river incision occurred at about 1.1-1.3 km from the slope foot, suggesting a mountainward tilting of the recently uplifted block. 


\section{CONCLUSIONS}

The slope we studied in the Italian Apennines represents the evolution of a fault line scarp generated under transpressional conditions and then affected by normal faulting at its foot. The Holocene history is in fact characterized by the deposition of slope deposits and reactivation as an extensional fault of the mountainwarddipping plane responsible for the genesis of the previous obsequent slope. Such a faulting provoked the recent rising of the area located between the carbonate slope and the present-day talweg by footwall uplift. As a consequence, the fluvial network running on the terrigenous rocks forming this glacis deepened their riverbeds, and large landslides, widespread in the clay-dominated units, was likely also triggered by such a recent tectonic activity.

The entire southern Apennines are featured by more or less well-preserved remnants of flat or weakly undulating land surfaces resulting by planation episodes related to ancient base levels of erosion. Such polygenic landforms are often located at the top of the ridges (i.e. the summit land surface or low-relief palaeolandscape, called "Paleosuperficie" or S1 by the Italian authors) and have been originally generated at the sea level, mainly by marine erosion, during the Pliocene-Pleistocene transition. Uplift, faulting and displacement of this landform have been responsible for its morphological de-activation and the consequent generation of the S2 land surfaces, mainly featured by a fluvial-karstic low-relief landscape, as a product of a significant re-working of the S1 remnants in a continental environment. Both their diffusion along the chain and the well-known ages of deformation made the S1 and S2 land surfaces suitable regional markers for morphotectonic and neotectonic studies. Regional uplift rates calculated using the tectonic displacement and consequent morphological de-activation of the S1 and S2 palaeosurfaces of the study area, at 1.8 and $1.2 \mathrm{Ma}$ respectively, vary from 0.72 to $0.96 \mathrm{~mm} / \mathrm{a}$. Such values are very slightly different from those $(0.66$ e $0.75 \mathrm{~mm} / \mathrm{a}$, respectively) estimated by Schiattarella et al. (2003) for the entire mountainous region surrounding the PergolaMelandro basin using the same morphological markers. The weak decimal spread among the average values of the regional-scale uplift rates and those calculated for the study area can be attributed to the contribution of the local tectonics due to the lower Pleistocene transpressional faulting and expressed by the present-day morphological offset of the Coste di Brienza slope (Fig. 10). The difference between the long-term uplift and denudation rates reflects a non-steady state condition of the growing local relief during Pleistocene times, as to the rest of the chain (Schiattarella et al., 2008). However, this work proves that many local complications may even produce a good match between erosion and uplift rates in more recent times. In this framework, the Coste di Brienza mountain front shows peculiar features due to a more complex geomorphic evolution which has made it a paradigmatic case-history.

\section{ACKNOWLEDGEMENTS}

This study was financially supported by Fondi di Ateneo RIL 2008-2011 (Basilicata University) granted to S.I. Giano and M. Schiattarella. Preparation and analysis of samples are due to the R.J. Van de Graaff Laboratory of the Utrecht University. We wish to thank referees and editors for the accurate review of the original manuscript.

\section{REFERENCES}

Aldega L, Corrado S, Di Leo P, Giampaolo C, Invernizzi C, Martino C, Mazzoli S, Schiattarella M and Zattin M, 2005. The southern Apennines case history: thermal constraints and reconstruction of tectonic and sedimentary burials. Atti Ticinensi di Scienze della Terra 10: 45-53.

Amato A, Aucelli PPC and Cinque A, 2003. The long-term denudation rate in the Southern Apennines Chain (Italy): a GIS-aided estimation of the rock volumes eroded since middle Pleistocene time. Ouaternary International 101-102: 3-11, DOI 10.1016/S10406182(02)00087-3.

Ascione A and Cinque A, 1997. Le scarpate su faglia dell'Appennino meridionale: genesi, età e significato tettonico (Fault scarps from the southern Apennines: origin, age, and tectonic significance). Il Quaternario, Italian Journal of Quaternary Sciences 10: 285-292 (in Italian).

Ascione A and Cinque A, 2003. Le variazioni geomorfologiche indotte dalla tettonica recente in Appennino meridionale (Morphological changes induced by recent tectonics in the southern Apennines). Il Quaternario, Italian Journal of Quaternary Sciences 16: 133-140 (in Italian).

Athanassios G, Shanov S, Drakatos G, Dobrev N, Sboras S, Tsimi C, Frangov G and Pavlides S, 2005. Active fault segmentation in southwest Bulgaria and Coulomb stress triggering of the 1904 earthquake sequence. Journal of Geodynamics 40(2-3): 316-333, DOI 10.1016/j.jog.2005.07.017.

Boenzi F, Capolongo D, Cecaro G, D'Andrea E, Giano SI, Lazzari M and Schiattarella M, 2004. Evoluzione geomorfologica polifasica e tassi di sollevamento del bordo sud-occidentale dell'alta Val d'Agri, Appennino meridionale (Morphostructural evolution and uplift rates of the western side of the upper Agri River valley, southern Apennines, Italy). Bollettino della Società Geologica Italiana, Italian Journal of Geosciences 123: 357-372 (in Italian).

Brancaccio L, Cinque A and Sgrosso I, 1978. L'analisi morfologica dei versanti come strumento per la ricostruzione degli eventi neotettonici (Morphological analysis of slopes as a tool for the reconstruction of neotectonic events). Memorie della Società Geologica Italiana 19: 621-626 (in Italian).

Brancaccio L, Cinque A and Sgrosso I, 1979. Forma e genesi di alcuni versanti di faglia in rocce carbonatiche: il riscontro naturale di un modello teorico (Landforms and genesis of some fault slopes in carbonate rocks: the natural response of a theoretical model). Rendiconti Accademia Scienze Fisiche e Matematiche serie IV 46: 121 (in Italian).

Brancaccio L, Cinque A and Sgrosso I, 1986. Elementi morfostrutturali ereditati nel paesaggio dell'Appennino centro-meridionale (Inherited morphostructural elements in the landscape of the centralsouthern Apennines). Memorie della Società Geologica Italiana 35: 869-874 (in Italian).

Bronk Ramsey C and Lee S, 2013. Recent and Planned Developments of the Program OxCal. Radiocarbon 55(2-3): 720-773.

Brunsden D (Ed), 1971. Slope: Form and Process. Institute of British Geographers Spec. Publ. 3: 178 pp.

Burbank DW and Anderson RS, 2001. Tectonic Geomorphology. Blackwell Science, 274 pp. 
Ciaranfi N, Lirer F, Lirer L, Lourens LJ, Maiorano P, Marino M, Petrosino P, Sprovieri M, Stefanelli S, Brilli M, Girone A, Joannin S, Pelosi N and Vallefuoco M, 2010. Integrated stratigraphy and astronomical tuning of lower-middle Pleistocene Montalbano Jonico section (southern Italy). Quaternary International 219(1-2): 109120, DOI 10.1016/j.quaint.2009.10.027.

Cinque A, Patacca E, Scandone P and Tozzi M, 1993. Quaternary kinematic evolution of the Southern Apennines. Relationships between surface geological features and deep lithospheric structures. Annali di Geofisica 36: 249-260.

Cotton CA, 1950. Tectonic scarps and fault valleys. Geological Society of America Bulletin 61(7): 717-757, DOI 10.1130/00167606(1950)61[717:TSAFV]2.0.CO;2.

Di Leo P, Gioia D, Martino C, Pappalardo A and Schiattarella M, 2011. Geomorphological, mineralogical, and geochemical evidence of Pleistocene weathering conditions in the southern Italian Apennines. Geologica Carpathica 62(1): 43-53, DOI 10.2478/v10096-011-0004-0.

Di Nocera S, Russo B and Torre M, 1982. I depositi marini del ciclo Pliocene inferiore-medio nei dintorni di Vietri di Potenza (Lowermiddle Pliocene marine deposits near Vietri di Potenza). Rendiconti Accademia Scienze Fisiche e Matematiche 45: 87-105 (in Italian).

Font M, Lagarde JL, Amorese,D, Coutard J-P, Dubois A, Guillemet G, Ozouf JC and Vedie E, 2006. Physical modelling of fault scarp degradation under freeze-thaw cycles. Earth Surface Processes and Landforms 31(14): 1731-1745, DOI 10.1002/esp.1371.

Giano SI and Martino C, 2003. Assetto morfotettonico e morfostratigrafico di alcuni depositi continentali pleistocenici del bacino del Pergola-Melandro, Appennino Lucano (Morphostructural and morphostratigraphic setting of Pleistocene continental deposits of the Pergola-Melandro basin, Lucanian Apennine). Il Quaternario, Italian Journal of Quaternary Sciences 16: 289-297 (in Italian).

Giano SI, Maschio L, Alessio M, Ferranti L, Improta S and Schiattarella M, 2000. Radiocarbon dating of active faulting in the Agri high valley, southern Italy. Journal of Geodynamics 29(3-5): 371-386, DOI 10.1016/S0264-3707(99)00058-7.

Gioia D, Martino C and Schiattarella M, 2011. Long- to short-term denudation rates in the southern Apennines: geomorphological markers and chronological constraints. Geologica Carpathica 62(1): 27-41, DOI 10.2478/v10096-011-0003-1.

Hartvich F and Mentlík P, 2010. Slope development reconstruction at two sites in the Bohemian Forest Mountains. Earth Surface Processes and Landforms 35(4): 373-389, DOI 10.1002/esp.1932.

Hartvich F and Valenta J, 2013. Tracing an intra-montane fault: an interdisciplinary approach. Surveys in Geophysics 34(3): 317-347, DOI 10.1007/s10712-012-9216-9.

Johnson D, 1939. Fault scarps and fault-line scarps. Journal of Geomorphology 2: 174-177.

Kirkby MJ, 1971. Hillslope process-response models based on the continuity equation. In: Brunsden D, ed., Slope: Form and Process. Institute of British Geographers Special Publication n. 3: 15-30.

Kirkby MJ, 1984. Modelling cliff development in South Wales: Savigear re-viewed. Zeitschrift für Geomorphologie 28: 405-426.

Krzyszkowski D and Stachura R, 1998. Neotectonically controlled fluvial features, Walbrzych: Middle Sudeten Mts, southwestern Poland. Geomorphology 22(1): 73-91, DOI 10.1016/S0169555X(97)00040-8.

Lazzari M and Schiattarella M, 2010. Estimating long to short-term erosion rates of fluvial vs mass movement processes: an example from the axial zone of the southern Italian Apennines. Italian Journal of Agronomy 5: 57-66, DOI 10.4081/ija.2010.s3.57.

Machette MN, 2000. Active, capable, and potentially active faults - a paleoseismic perspective. Journal of Geodynamics 29(3-5): 387392, DOI 10.1016/S0264-3707(99)00060-5.

Martino C, Nico G and Schiattarella M, 2009. Quantitative analysis of InSAR Digital Elevation Models for identification of areas with different tectonic activity in southern Italy. Earth Surface Processes and Landforms 34(1): 3-15, DOI 10.1002/esp.1681.

Martino C and Schiattarella M, 2006. Aspetti morfotettonici dell'evoluzione geomorfologica della valle del Melandro, Appennino campano-lucano (Morphotectonics and Quaternary geomorphological evolution of the Melandro Valley, southern Apennines,
Italy). Il Quaternario, Italian Journal of Quaternary Sciences 19: $119-128$ (in Italian).

Martino C and Schiattarella M, 2010. Relationships among climate, uplift and palaeo-landslides generation in the Melandro River basin, southern Apennines, Italy. Geografia Fisica e Dinamica Quaternaria 33: 37-43.

Mazzoli S, D'Errico M, Aldega L, Corrado S, Invernizzi C, Shiner P and Zattin M, 2008. Tectonic burial and "young" $(<10 \mathrm{Ma})$ exhumation in the southern Apennines fold-and-thrust belt (Italy). Geology 36(3): 243-246, DOI 10.1130/G24344A.1.

McCalpin JP and Berry ME, 1996. Soil catenas to estimate ages of movements on normal fault scarps, with an example from the Wasatch fault zone, Utah, USA. Catena 27(3-4): 265-286, DOI 10.1016/0341-8162(96)00020-3.

Moro M, Amicucci L, Cinti FR, Doumaz F, Montone P, Pierdominici S, Saroli M, Stramondo S and Di Fiore B, 2007. Surface evidence of active tectonics along the Pergola-Melandro fault: A critical issue for the seismogenic potential of the southern Apennines, Italy. Journal of Geodynamics 44(1-2): 19-32, DOI 10.1016/j.jog.2006.12.003

Ortuño M, Queralt P, Martí A, Ledo J, Masana E, Perea H and Santanach P, 2008. The North Maladeta Fault (Spanish Central Pyrenees) as the Vielha 1923 earthquake seismic source: Recent activity revealed by geomorphological and geophysical research. Tectonophysics 453(1-4): 246-262, DOI 10.1016/j.tecto.2007.06.016.

Pescatore T, Renda P, Schiattarella M and Tramutoli M, 1999. Stratigraphic and structural relationships between Meso-Cenozoic Lagonegro basin and coeval carbonate platforms in southern Apennines, Italy. Tectonophysics 315(1-4): 269-286, DOI 10.1016/S0040-1951(99)00278-4.

Reimer PJ, Bard E, Bayliss A, Beck W, Blackwell PG, Bronk Ramsey C, Buck CE, Cheng H, Edwards RL, Friedrich M, Grootes PM, Guilderson TP, Haflidason H, Hajdas I, Hatté C, Heaton TJ, Hoffmann DL, Hogg AG, Hughen KA, Kaiser KF, Kromer B, Manning SW, Niu M, Reimer RW, Richards DA, Scott EM, Southon JR, Staff RA, Turney CSM, van der Plicht J, 2013. Intcal13 and Marine13 Radiocarbon Age Calibration Curves 050,000 Years Cal BP. Radiocarborn 55(4): 1869-1887.

Ruggieri G, Rio D and Sprovieri R, 1984. Remarks on the chronostratigraphic classification of lower Pleistocene. Bollettino della Società Geologica Italiana 103: 251-259.

Russo F and Schiattarella M, 1992. Osservazioni preliminari sull'evoluzione morfostrutturale del bacino di Castrovillari, Calabria settentrionale (Preliminary data on the morphostructural evolution of the Castrovillari basin, Northern Calabria, Italy). Studi Geologici Camerti Spec. Vol. 1992/1: 271-278 (in Italian).

Schiattarella M, 1998. Quaternary tectonics of the Pollino Ridge, Calabria-Lucania boundary, southern Italy. In: Holdsworth RE, Strachan RA and Dewey JF, eds., Continental Transpressional and Transtensional Tectonics. Geological Society of London Spec. Vol. 135: 341-354.

Schiattarella M, Beneduce P, Capolongo D, Di Leo P, Giano SI, Gioia D, Lazzari M and Martino C, 2008. Uplift and erosion rates from the southern Apennines, Italy. Bollettino di Geofisica Teorica ed Applicata 49(2): 470-475.

Schiattarella M, Di Leo P, Beneduce P and Giano SI, 2003. Quaternary uplift vs tectonic loading: a case-study from the Lucanian Apennine, southern Italy. Quaternary International 101-102: 239-251, DOI 10.1016/S1040-6182(02)00126-X.

Schiattarella M, Di Leo P, Beneduce P, Giano SI and Martino C, 2006. Tectonically driven exhumation of a young orogen: An example from the southern Apennines, Italy. In: Willett SD, Hovius N, Brandon MT and Fisher DM, eds., Tectonics, climate, and landscape evolution. Geological Society of America Special Paper 398: 371-385.

Shanov SB and Dobrev ND, 1997. Impact of the seismic processes on the movements along the Kroupnik fault zone (SW Bulgaria). Comptes rendus de l'Académie bulgare des Sciences 6: 95-98.

Wallace RE, 1977. Profiles and ages of young fault scarps, north-central Nevada. Geological Society of America Bulletin 88(9): 1267-1281, DOI 10.1130/0016-7606(1977)88<1267:PAAOYF >2.0.CO;2.

Young A, 1972. Slopes. Oliver \& Boyds Edimburg: 1-288. 